\title{
Growth, fruit set and yield of Santa Rosa plum as affected by nitrogen and boron under rainfed conditions of Kashmir Valley
}

\author{
G. A. Dar ${ }^{1}$, F. A. Misger ${ }^{2}$, Amit Kumar ${ }^{3 *}$ and J. A. Rather ${ }^{4}$ \\ Shalimar, Srinagar-190025 (J\&K), INDIA \\ *Corresponding author. E-mail: khokherak@rediffmail.com \\ Received: November 26, 2015; Revised received: July30, 2016; Accepted: November 10, 2016
}

Division of Fruit Science, Sher-E-Kashmir University of Agricultural Sciences and Technology of Kashmir,

Abstract: Present experiment was carried out in a seven year old private plum orchard near SKUAST-Kashmir, Shalimar Campus, Srinagar during 2012 and 2013, to examine the response to nitrogenous fertilizer and boron on growth, fruit set and yield of plum var. Santa Rosa. Urea @ $500 \mathrm{~g}\left(\mathrm{~N}_{1}\right), \mathrm{CaNO}_{3} @ 1450 \mathrm{~g}\left(\mathrm{~N}_{2}\right), \mathrm{N}_{1}+50 \mathrm{~g}$ boron $\left(\mathrm{N}_{3}\right)$ and $\mathrm{N}_{2}+50 \mathrm{~g}$ boron $\left(\mathrm{N}_{4}\right)$ were applied at $\mathrm{T}_{1}=$ Full dose in spring, $\mathrm{T}_{2}=$ Full dose after harvest and $\mathrm{T}_{3}=3 / 4$ dose in spring and $1 / 4$ dose after harvest. Observations were recorded on parameters viz. incremental tree girth, shoot extension growth, plant height, plant spread, leaf area, fruit set, fruit drop, yield, yield efficiency. All the growth parameters were high in treatment combination $\mathrm{N}_{1} \mathrm{~T}_{1}$. Maximum fruit set $\left(19.68 \%\right.$ and $20.90 \%$ ) was recorded in $\mathrm{N}_{3} \mathrm{~T}_{2}$, yield $(20.60 \mathrm{~kg} /$ tree and $22.88 \mathrm{~kg} /$ tree $)$ was recorded in $\mathrm{N}_{4} \mathrm{~T}_{2}$, yield efficiency $\left(0.45\right.$ and $\left.0.46 \mathrm{~kg} / \mathrm{cm}^{2}\right)$ was recorded in $\mathrm{N}_{4} \mathrm{~T}_{2}$ and minimum fruit drop (4.25\% and $4.55 \%$ ) were recorded under the treatment combination $\mathrm{N}_{4} \mathrm{~T}_{2}$ and $\mathrm{N}_{4} \mathrm{~T}_{3}$, respectively in the both the years. Both sources of nitrogen and boron can be considered as best fertilizer in plum orchards for improving the growth, fruit set, fruit yield, yield efficiency.

Keywords: Fertilizers, Fruit drop, Fruit set, Growth, Yield, Yield efficiency

\section{INTRODUCTION}

Prunus salicina plum is more vigorous, productive, precocious in bearing and disease resistant than the Prunus domestica. In India, plums are grown on a commercial scale in Jammu and Kashmir, Himachal Pradesh, Uttarakhand and plains of Punjab, Haryana. Plum covers an area of 4870 ha with a production of 7937 MT in Jammu and Kashmir (Anonymous, 2015). Growth and yield of fruit trees are dependent upon a number of factors like proper moisture, air supply, suitable temperature, light conditions, insects-pests and diseases and balanced nutrition. Nutrients are essential for high productivity and good quality of fruit crops. Hence, the determination of nutritional needs for efficient production of high quality fruits is an important aspect of nutrient management for the orchardist. Nitrogen is usually applied annually to fruit crops and for which various sources are available such as nitrate, ammonium or in combination of both whereas the calcium nitrate is commonly used nitrogen fertilizer for fruit crops. The greatest limitation of this source is the low analysis $(15 \% \mathrm{~N})$ and after high cost per unit of nitrogen. Calcium nitrate has become the material of choice for fertilizing young fruit crops. The benefits of calcium nitrate fertilizers are taken up rapidly and stimulate strong early season growth. Boron is an essential trace element required for abundant yield and high quality fruit. But boron fertilization in fruit trees and especially in plum trees is seldom applied in Kashmir. In most cases, boron fertilization is used to eliminate boron deficiency symptoms in trees on the other hand, plum tree is a species which has high nutritional requirement with respect to boron. Particularly, high amount of boron in plants must be applied during flowering because boron plays an important role in pollen production its germination, pollen tube growth and cell division (Acar et al., 2010; Ganie et al., 2013). Hence, the determination of nutritional needs for efficient production of high quality fruits of plum is an important aspect of nutrient management for the orchardist. Keeping in view the above fact the present study was conducted to determine the proper nitrogenous and boron fertilizer, its dose and timing to obtain good growth and yield from Santarosa plum under rainfed conditions of Kashmir valley.

\section{MATERIALS AND METHODS}

Experimental site and soil health: The experiment was carried out at farmer's field for two successive seasons 2012 and 2013 near SKUAST-Kashmir, Shalimar, Srinagar (J \& K). The experimental orchard was situated at an altitude of $1685 \mathrm{~m}$ amsl which lying between $34^{\circ} 75^{\prime} \mathrm{N}$ latitude and $74^{\circ} 50$ ' E longitude. Most of the precipitation received from October to April and rest is erratically distributed Winters are severe extending from December to March and the temperature often goes below freezing point during 
this period. The analysis of soil indicated that the soil of the experimental site was clay-loam having $\mathrm{pH}$ (6.52), organic carbon (1.32\%), available N, P, K Ca, $\mathrm{Mg}, \mathrm{Fe}, \mathrm{Zn}, \mathrm{Cu}, \mathrm{Mn}$ was 110 ppm, 10.40 ppm, 120.50 ppm, 23.5 ppm, 17.0 ppm, 42 ppm, 1.15 ppm, 1.65 ppm, respectively.

Material involved: The study was carried out on seven years old plum trees cv. Santa Rosa under rainfed conditions grown on private plum orchard. Thirty six healthy trees of Santa Rosa plum were selected on the basis of uniform size, age and vigour. The selected plants were labeled and grouped into three replications and twelve treatments combinations. Trees were kept under a rigid schedule of uniform cultural operation

\begin{tabular}{cccc}
\hline \multirow{2}{*}{$\begin{array}{c}\text { Source } \\
\text { fertilizers }\end{array}$} & \multicolumn{3}{c}{ Time of fertilizer application } \\
\cline { 2 - 4 } $\mathrm{T}_{1}$ & $\mathbf{T}_{2}$ & $\mathbf{T}_{3}$ \\
\hline $\mathrm{N}_{2}$ & $\mathrm{~N}_{1} \mathrm{~T}_{1}$ & $\mathrm{~N}_{1} \mathrm{~T}_{2}$ & $\mathrm{~N}_{1} \mathrm{~T}_{3}$ \\
$\mathrm{~N}_{3}$ & $\mathrm{~N}_{2} \mathrm{~T}_{1}$ & $\mathrm{~N}_{2} \mathrm{~T}_{2}$ & $\mathrm{~N}_{2} \mathrm{~T}_{3}$ \\
$\mathrm{~N}_{4}$ & $\mathrm{~N}_{3} \mathrm{~T}_{1}$ & $\mathrm{~N}_{3} \mathrm{~T}_{2}$ & $\mathrm{~N}_{3} \mathrm{~T}_{3}$ \\
& $\mathrm{~N}_{4} \mathrm{~T}_{1}$ & $\mathrm{~N}_{4} \mathrm{~T}_{2}$ & $\mathrm{~N}_{4} \mathrm{~T}_{3}$ \\
\hline
\end{tabular}

including irrigation, fertilization, insect-pests and disease control during the entire period of investigation. The following treatment combinations were made.

The fertilizers were applied from various sources of fertilizers viz., $\mathrm{N}_{1}=$ Urea (500 g), $\mathrm{N}_{2}=$ Calcium nitrate $(1450 \mathrm{~g}), \mathrm{N}_{3}=$ Urea $(500 \mathrm{~g})+50 \mathrm{~g}$ Boron, $\mathrm{N}_{4}=$ Calcium nitrate $(1450 \mathrm{~g})+50 \mathrm{~g}$ Boron and at different times viz. $\mathrm{T}_{1}=$ Full dose in spring, $\mathrm{T}_{2}=$ Full dose after harvest, $T_{3}=3 / 4$ dose in spring and $1 / 4$ dose after harvest.

Observations recorded: Observations were recorded on growth parameters viz. incremental tree girth (at 30 $\mathrm{cm}$ above the graft union), shoot extension growth $(\mathrm{cm})$, plant height $(\mathrm{m})$, plant spread $(\mathrm{m})$ and leaf area $\left(\mathrm{cm}^{2}\right)$ was measured with the help of Systronic Leaf Area Meter-11, fruit parameters viz. fruit set (\%), fruit drop (\%), yield parameters viz. fruit yield $(\mathrm{kg} / \mathrm{tree})$, yield efficiency $\left(\mathrm{kg} / \mathrm{cm}^{2}\right)$ was determined as per formula (Westwood, 1993).

Statistical analysis: The data generated from these investigations were appropriately computed, tabulated and analyzed by applying Randomized Block Design Factorial (RBD). The level of significance was tested for different variable at 5 per cent level of significance (Gomez and Gomez, 1984).

\section{RESULTS AND DISCUSSION}

Growth characteristics: Perusal of data presented in Table 1 revealed significant observation with respect to different sources of fertilizers and time of application of fertilizers. The highest incremental tree girth $(2.93$ and $3.27 \mathrm{~cm})$ in both the years was recorded under the treatment combination of $\mathrm{N}_{1} \mathrm{~T}_{1}$ (urea $500 \mathrm{~g}$ full dose in spring) which was statistically higher among all the treatment combinations and the lowest $(0.85$ and $1.19 \mathrm{~cm}$ ) was recorded in $\mathrm{N}_{4} \mathrm{~T}_{2}$ (Calcium nitrate $1450 \mathrm{~g}+50 \mathrm{~g}$ borax full dose after harvest), respectively. Maximum shoot extension growth $(24.74 \mathrm{~cm})$

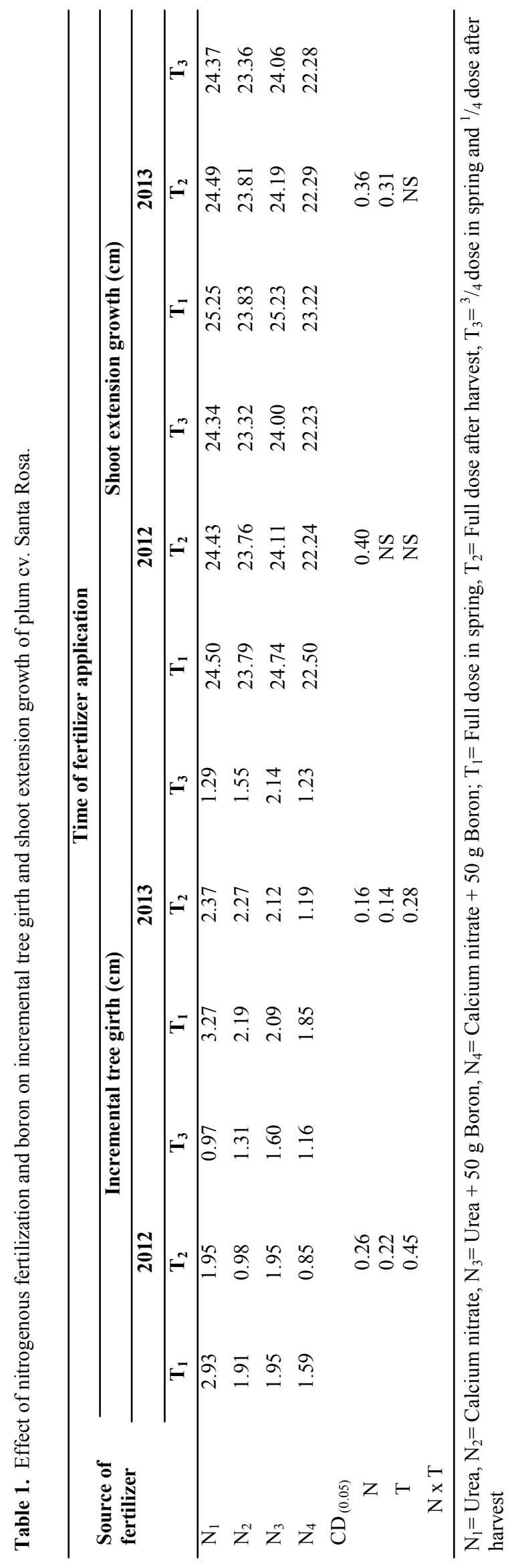


G. A. Dar et al. / J. Appl. \& Nat. Sci. 8 (4): 2081-2086 (2016)

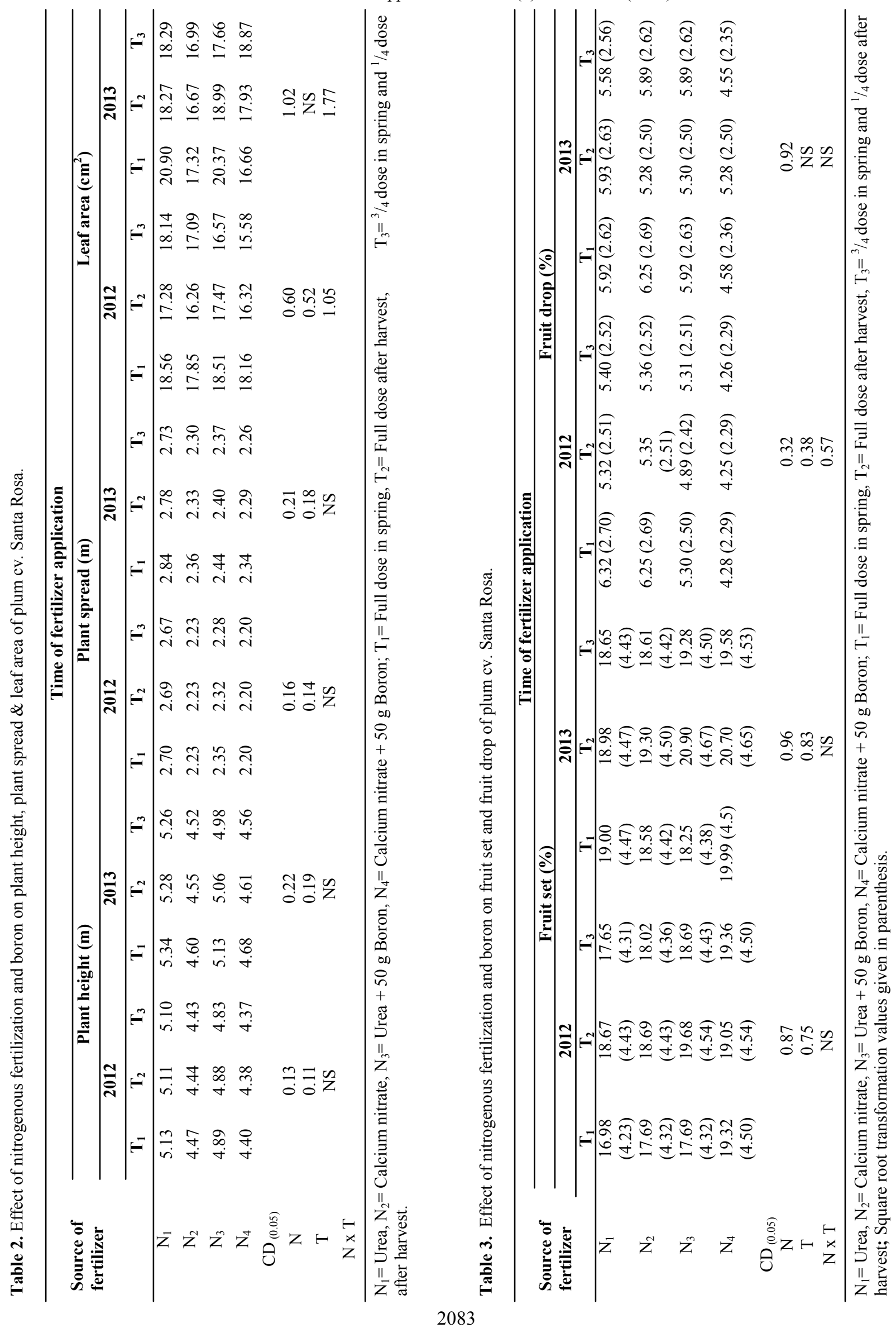




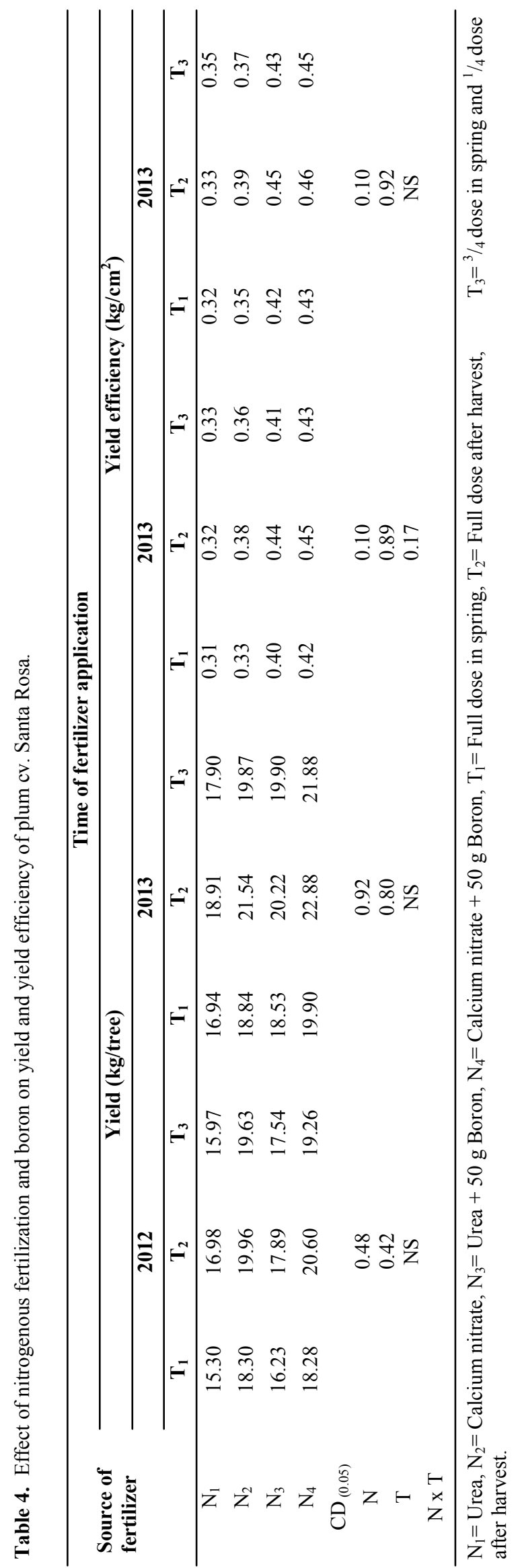

in the $1^{\text {st }}$ year i.e. 2012 was recorded in $\mathrm{N}_{3} \mathrm{~T}_{1}$ treatment which was statistically at par with $\mathrm{N}_{1} \mathrm{~T}_{1}(24.50 \mathrm{~cm})$, however in the year 2013 maximum extension growth of shoot was recorded in $\mathrm{N}_{1} \mathrm{~T}_{1}(25.25)$ which was statistically at par with $\mathrm{N}_{3} \mathrm{~T}_{1}(25.23 \mathrm{~cm})$. Minimum values for shoot extension growth was recorded in $\mathrm{N}_{4} \mathrm{~T}_{3}(22.23$ and $22.28 \mathrm{~cm}$ ) in 2012 and 2013, respectively. As such, the increase in vegetative growth due to urea sprays may be attributed to the fact that on hydrolysis the urea releases $\mathrm{NH}_{4}{ }^{+}$form for nitrogen uptake by the plants.

The plant height was significantly influenced by various treatments and recorded maximum (5.13 and 5.34 m) plant height with treatment combination $\mathrm{N}_{1} \mathrm{~T}_{1}$ in both the years and was statistically at par with respect to time of application however statistically higher among different sources of fertilizers (Table 2). $\mathrm{N}_{4} \mathrm{~T}_{3}$ $(4.37 \mathrm{~cm})$ and $\mathrm{N}_{2} \mathrm{~T}_{3}(4.52 \mathrm{~cm})$ registered minimum plant height in 2012 and 2013, respectively. Similar trend was observed with respect to plant spread except for minimum values that was observed in $\mathrm{N}_{4} \mathrm{~T}_{1}(2.20$ $\mathrm{cm}), \mathrm{N}_{4} \mathrm{~T}_{2}(2.20 \mathrm{~cm}), \mathrm{N}_{4} \mathrm{~T}_{3}(2.20 \mathrm{~cm})$ in the $1^{\text {st }}$ year and only in $\mathrm{N}_{4} \mathrm{~T}_{3}(2.26 \mathrm{~cm})$ in the second year of study. Jasso-chaverriaa et al. (2005) observed improvement in vegetative characteristics (plant height, stem diameter and number of leaves) with the increase in nitrogen fertilizer rate which is attributed to increased uptake of nitrogen and its associated role in chlorophyll synthesis and hence the process of photosynthesis and carbon dioxide assimilation leading to enhanced vegetative growth. However, Sarwar et al. (2007) observed that the effect of different nitrogenous fertilizers on plant height of tea were non-significant.

Maximum leaf area in both the year of study was recorded in $\mathrm{N}_{1} \mathrm{~T}_{1}\left(18.56\right.$ and $\left.20.90 \mathrm{~cm}^{2}\right)$ which was statistically at par with $\mathrm{N}_{1} \mathrm{~T}_{3}$ in case of time of application of fertilizer only in the $1^{\text {st }}$ year of study however it was statistically higher in the $2^{\text {nd }}$ year of study (Table 2 ). In case of source of fertilizer maximum value of leaf area (18.56) was statistically at par with $\mathrm{N}_{3} \mathrm{~T}_{1}\left(18.51 \mathrm{~cm}^{2}\right)$ and $\mathrm{N}_{4} \mathrm{~T}_{1}\left(18.16 \mathrm{~cm}^{2}\right)$ in the $1^{\text {st }}$ year of study, however it was non-significant in the $2^{\text {nd }}$ year of study. Minimum values for leaf area was registered in the treatment combination of $\mathrm{N}_{4} \mathrm{~T}_{3}\left(15.58 \mathrm{~cm}^{2}\right)$ in 2012 and $\mathrm{N}_{4} \mathrm{~T}_{1}\left(16.66 \mathrm{~cm}^{2}\right)$ in 2013 , respectively. Increase in leaf area was due to high concentration of nitrogen and boron which have important effect on development of leaf cells (Malakouti et al., 2005).

Fruit set and fruit drop: Treatment combination of $\mathrm{N}_{3} \mathrm{~T}_{2}(19.68$ and $20.90 \%)$ recorded maximum fruit set in 2012 and 2013, respectively which was statistically higher with respect to time of application of fertilizers however at par with $\mathrm{N}_{4} \mathrm{~T}_{2}(19.05$ and $20.70 \%)$ in case of source of fertilizers (Table 3 ). Minimum fruit set was recorded with treatment combination of $\mathrm{N}_{1} \mathrm{~T}_{1}$ $(16.98 \%)$ and $\mathrm{N}_{3} \mathrm{~T}_{1}(18.25 \%)$ in $1^{\text {st }}$ and $2^{\text {nd }}$ year of study, respectively. Sarrwy et al. (2012) also observed best fruit setting by spraying boric acid at $500 \mathrm{ppm}$ 
mixed with calcium nitrate at 2 per cent (78 and $79 \%$ in two seasons, respectively), followed by treatment of boric acid at $250 \mathrm{ppm}$ mixed with calcium nitrate 2 per cent (75 and $76 \%$ ). Abdel-Hafeez et al. (2010) on Kelsey plum and Wojcik and Wojcik (2006) on sweet cherry also report similar results. Ganie et al. (2013) also observed that increasing fruit set in apple due to boron may be attributing to its role in maintaining higher pollen viability and germination.

Fruit drop was significantly influenced by various treatments during both the years of studies (Table 3 ). Maximum (6.32 and $5.81 \%$ ) fruit drop in the $1^{\text {st }}$ year of study i.e. 2012 was recorded in the treatment combination of $\mathrm{N}_{1} \mathrm{~T}_{1}(6.32 \%)$ which was statistically higher in case of time of application of fertilizer however at par with $\mathrm{N}_{2} \mathrm{~T}_{1}(6.25 \%)$ in case of source of fertilizer. In 2013, $\mathrm{N}_{2} \mathrm{~T}_{1}$ treatment combination registered maximum fruit drop $(6.25 \%)$ which was statistically at par with $\mathrm{N}_{2} \mathrm{~T}_{3}(5.89 \%)$ with respect to time of application of fertilizers however in case of source of fertilizer it the results were non-significant. Minimum fruit drop in 2012 and 2013 was recorded in treatment combinations of $\mathrm{N}_{4} \mathrm{~T}_{2}(4.25 \%)$ and $\mathrm{N}_{4} \mathrm{~T}_{3}(4.55 \%)$. This coincides with the findings of maximum fruit set under the same treatment calcium nitrate $1450 \mathrm{~g}+50 \mathrm{~g}$ borax full dose after harvest during the studies, so it is obvious that minimum fruit drop under the treatment will be accompanied by highest fruit set due to pollen viability, germination and pollen tube growth as a result of application of calcium nitrate along with boron. However, Abd El-Ghany (2005) reported that the initial drop occurred due to competition among the fruits on the nutrients, water and the defect in hormonal balance.

Fruit yield and yield efficiency: Maximum fruit yield (20.60 and $22.88 \mathrm{~kg} /$ tree) along with maximum yield efficiency $\left(0.45\right.$ and $\left.0.46 \mathrm{~kg} / \mathrm{cm}^{2}\right)$ was recorded in the treatment combination $\mathrm{N}_{4} \mathrm{~T}_{2}$ in 2012 and 2013, respectively (Table 4). Maximum yield in both the years was statistically higher among other treatment combination in case of source of fertilizers and time of application of fertilizer, however yield efficiency was statistically at par with $\mathrm{N}_{4} \mathrm{~T}_{3}\left(0.43\right.$ and $\left.0.45 \mathrm{~kg} / \mathrm{cm}^{2}\right), \mathrm{N}_{4} \mathrm{~T}_{1}(0.42$ and $0.43 \mathrm{~kg} / \mathrm{cm}^{2}$ ) in case of time of application of fertilizers and at par with $\mathrm{N}_{3} \mathrm{~T}_{2}\left(0.44\right.$ and $\left.0.45 \mathrm{~kg} / \mathrm{cm}^{2}\right)$ and $\mathrm{N}_{2} \mathrm{~T}_{2}\left(0.38\right.$ and $\left.0.39 \mathrm{~kg} / \mathrm{cm}^{2}\right)$ in case of source of fertilizers. Minimum values for fruit yield (15.30 and 16.94 $\mathrm{kg} /$ tree $)$ and yield efficiency $\left(0.31\right.$ and $\left.0.32 \mathrm{~kg} / \mathrm{cm}^{2}\right)$ in both the years i.e. 2012 and 2013 was recorded in the treatment combination of $\mathrm{N}_{1} \mathrm{~T}_{1}$. Spraying of boron and calcium increased bunch weight of date palm (Sarrwy et al., 2012) and it may also attribute that boron enhance many metabolic processes such as transportation of carbohydrates (Mengel and Kirkby, 2001) and sugars in snowball cultivar of cauliflower (Kumar et al., 2013). These high figures of yield efficiency are indicative of physiological efficient tree, because the ratio of apple fruit yield to trunk girth is better balanced in this treatment compared to other treatments. However, all the vegetative growth is not necessary for maximum yield because of negative correlation between yield and vegetative growth (Rumayor-Rodriguez and Bravo-lozano, 1991). This also corresponds well with the treatment under which the fruit set in peach was higher and resulted in higher yield (El-Boray et al., 2013).

\section{Conclusion}

Thus it is concluded that results showed that the various growth parameters viz incremental tree girth, shoot extension growth, plant height and plant breadth of Santa Rosa plum were influenced by the application of nitrogen through urea $500 \mathrm{~g}$ full dose in spring. Similarly other fruiting attributes like fruit set, reduction in fruit drop, fruit yield and fruit yield efficiency were improved by the application of calcium nitrate $1450 \mathrm{~g}$ $+50 \mathrm{~g}$ borax full dose after harvest. Due to imbalance use of fertilizers which affects the soil and plant health and also increases the input expenditure and thus to overcome such problem, judicious use of nitrogenous fertilizer and boron improves growth, fruit set and yield and reduces fruit drop.

\section{REFERENCES}

Abd El-Ghany, N.A. (2005). Fruit drop. Agricultural Journal 60(3): 21-22

Acar, I., Ak, B.E. and Sarpkaya, K. (2010). Effects of boron and gibberellic acid on in vitro pollen germination of pistachio (Pistacia vera L.). African Journal of Biotechnology, 9(32): 5126-5130

Abdel-Hafeez, A.A., Azza, I., Mohamad, N., Taha, M. and Mehaiesn, S.M.A. (2010). Effect of some sources of potassium and calcium as foliar sprays on fruit quality of storability of Kelsey plum. Egyptian Journal of Horticulture, 37(2): 65-73

Anonymous (2015). A report on fruit area and production 2014-2015. Directorate of Horticulture, Kashmir (J \& K Government) pp. 1-2.

El-Boray, M.S., Shalan, A.M. and Khouri, Z.M. (2013). Effect of different thinning techniques on fruit set, leaf area, yield and fruit quality parameters of Prunus persica L. Batsch cv. Floridaprince. Trends in Horticultural Research, 3: 1-13

Ganie, M.A., Akhter, F., Bhat, M.A., Malik, A.R., Junaid, J.M, Shah, M.A., Bhat, A.H and Bhat, T.A. (2013). Boron-a critical nutrient element for plant growth and productivity with reference to temperate fruits. Current Science, 104: 76-85

Gomez, K.A. and Gomez, A.A. (1984). Statistical Procedure for Agricultural Research, John Willey and sons, New York.

Jasso-Chaverria, C., Hochmuth, G.J., Hochmuth, R.C. and Sargent, S.A. (2005). Fruit yield, size, and colour responses of two Greenhouse cucumber types to nitrogen fertilization in perlite soilless culture. Horticulture Technology, 15: 565

Kumar, C., Raturi, H.C. and Uniyal, S.P. (2013). Response of boron and lime application on growth and seed yield 
of snowball cauliflower (Brassica oleracea var. botrytis L.) cv. PSBK-1. The Asian Journal of Horticulture, 8: 246-249

Malakouti, M.J., Majidi, A., Sacheshmepour, M., Dehghani, F., Shahabi, A.A., Keshavarz, P., Basirat, M., Rastegar, H., Taheri, M., Gandomkar, A., Tadayon, M.S., Asadi, A., Kiani, S., Bybordi, A., Mahmoudi, M., Saleh, J., Mostasharim, M., Manouchehri, S., Afkhami, M., Rasouli, M.H. and Mozaffari, V. (2005). Nutritional disorders, determination of quality indices and optimum levels of nutrients in fruits grown on the calcareous soils of Iran, Soil and Water Research Institute, Sana Publication, pp. 319-325

Mengel, K. and Kirkby, E.A. (2001). Principles of Plant Nutrition $5^{\text {th }}$ Edition Kluwer, p. 847

Rumayor-Rodriguez, A. and Bravo-Lozano, A. (1991). Effect of three systems and levels of irrigation apple trees.
Scientia Horticulturae, 47: 67-75

Sarwar, S., Ahmad, F., Hamid, F.S., Khan, B.M. and Khurshid, F. (2007). Effect of different nitrogenous fertilizers on the growth and yield of three years old tea (Camellia sinensis) plants. Sarhad Journal of Agriculture, 23(4): 25-30

Sarrwy, S.M.A., Gadalla, E.G. and Mostafa, E.A.M. (2012). Effect of calcium nitrate and boric acid sprays on fruit set, yield and fruit quality of cv. Amhat date palm. World Journal of Agricultural Sciences, 8(5): 506-515

Westwood, M.N. (1993). Temperate zone Pomology. W.H. Freeman and Company, San Francisco, California, USA, pp. 223

Wojcik, P. and Wojcik, M. (2006). Effect of boron and fertilization on sweet cherry tree yield and fruit quality. Journal of Plant Nutrition, 29: 1755-1766 